DOI:10.2478/v10129-009-0002-X

$$
\text { Grzegorz Żurek }{ }^{1} \text {, Bartosz Tomaszewski }{ }^{2}
$$

${ }^{1}$ Department of Grasses, Legumes and Energy Plants, Laboratory of Nonfooder Grasses and Energy Plants, Radzików, 05-870 Błonie; ${ }^{2}$ Centre for Plant Genetic Resources, Botanical Garden, 85-687 Bydgoszcz

\title{
LOW MAINTENANCE TURF - QUALITY AND WEED ASPECTS
}

\begin{abstract}
Turfgrass varieties of Festuca rubra ssp. rubra, F.r. ssp. trichophylla, F. nigrescens, F.arundinacea, F.ovina ssp. vulgaris, F.o. ssp duriuscula, Lolium perenne and Poa pratensis as well as mixtures of high and low share of Lolium perenne were tested in low maintenance conditions during 5 years and evaluated for: shoot density, visual merit and for weed infestation. None of tested entries was able to keep initial quality. Only for few of them (mostly varieties of Festuca ovina ssp. duriuscula and F.arundinacea) visual merit after 5 years was still close to the level of minimal user-accepted value (5 in 1-9 scale). The least visual merit values were noted for Poa pratensis and Festuca rubra ssp. rubra. Twenty weed species of different living forms (geophytes, hemicryptophytes and terophytes) were described. Considering general turf performance, low number of weed species and low number of terophytes, turf mixtures with low share of perennial ryegrass could be recommended for low-maintenance turf.
\end{abstract}

Key words: Festuca arundinacea, Festuca nigrescens, Festuca rubra, Festuca ovina, Lolium perenne, low-input, cultivars, mixtures, Poa pratensis

\section{INTRODUCTION}

Along with increasing environment pollution, water deficits and other resources scarcity, demands for low input technologies in agriculture, gardening or other environment-related technologies are growing. Turf is often the most visible of plantings in urban areas and in many countries there is an increasing public pressure for the turfgrass industry to reduce maintenance inputs (Mintenko et al. 2002). Even under intensive management, the goal of turf sustainability is becoming more of a reality than a hope, as turfgrass scientists and managers have worked to identify turfgrass management systems that are more efficient, thus requiring less inputs. Low maintenance turf is therefore the only one reasonable possibility to cover large, municipal green areas due to its ecological role and potential resources savings.

Despite of turf quality aspects, little research is currently present on spontaneous weed infestation on turf areas, with regards on natural 'defensive' Communicated by Andrzej Aniot 
ability of grass species to cope with weeds. Therefore, the aim of our studies was to evaluate turf quality of some turf grass varieties and mixtures, along with weed infestation under 5 years of low maintenance management.

Species, varieties and mixtures used in experiment with species share during sowing

Table 1

\begin{tabular}{|c|c|c|c|c|c|c|c|c|}
\hline \multirow{2}{*}{ No. } & \multirow{2}{*}{$\begin{array}{l}\text { Genus, species, mixture type } \\
\text { (genus code) }\end{array}$} & \multirow{2}{*}{$\begin{array}{l}\text { Variety name, } \\
\text { mixture no }\end{array}$} & \multicolumn{6}{|c|}{ Species share during sowing [\%] } \\
\hline & & & L.p. & F.r. & P.p. & F.o. & A.c. & F.a. \\
\hline 1 & & Bartes & & & & & & 100 \\
\hline 2 & Festuca arundinacea (F.a.) & Skarpa & & & & & & 100 \\
\hline 3 & & Terros & & & & & & 100 \\
\hline 4 & & Lifalla & & 100 & & & & \\
\hline 5 & Festuca nigrescens (F.n.) & Nimba & & 100 & & & & \\
\hline 6 & & WOM-198 & & 100 & & & & \\
\hline 7 & & Espro & & & & 100 & & \\
\hline 8 & $\begin{array}{l}\text { Festuca ovina ssp. duriuscula } \\
\text { (F.o.d.) }\end{array}$ & Gabi & & & & 100 & & \\
\hline 9 & & Mimi & & & & 100 & & \\
\hline 10 & & Livina & & & & 100 & & \\
\hline 11 & $\begin{array}{l}\text { Festuca ovina ssp. vulgaris } \\
\text { (F.o.v.) }\end{array}$ & Noni & & & & 100 & & \\
\hline 12 & & Witra & & & & 100 & & \\
\hline 13 & & Areta & & 100 & & & & \\
\hline 14 & Festuca rubra ssp. rubra (F.r.r.) & Ensylva & & 100 & & & & \\
\hline 15 & & Leo & & 100 & & & & \\
\hline 16 & & Adio & & 100 & & & & \\
\hline 17 & $\begin{array}{l}\text { Festuca rubra ssp. trichophylla } \\
\text { (F.r.t.) }\end{array}$ & Barcrown & & 100 & & & & \\
\hline 18 & & WOM-298 & & 100 & & & & \\
\hline 19 & & Lisuna & 100 & & & & & \\
\hline 20 & Lolium perenne (L.p.) & Nira & 100 & & & & & \\
\hline 21 & & Stadion & 100 & & & & & \\
\hline 22 & & Conni & & & 100 & & & \\
\hline 23 & Poa pratensis (P.p.) & Cynthia & & & 100 & & & \\
\hline 24 & & Limusine & & & 100 & & & \\
\hline
\end{tabular}

\section{MATERIALS AND METHODS}

Turf experiment on 24 turf grass varieties and 6 commercial turf mixtures was carried out from 2002 to 2006 (Table 1). Experiment was conducted in 
central Poland, on lessive, sandy-loam soil. Area planned for this experiments laid fallow for 4 years, with frequent surface cultivation to reduce weeds emerging from seed soil bank. Starting fertilization $(60 \mathrm{~kg} \mathrm{~N}, 120 \mathrm{Kg}$ $\mathrm{P}, 120 \mathrm{~kg} \mathrm{~K}$ per ha) was applied and grass seed was sown in April of 2001 on randomized plots $\left(1 \mathrm{~m}^{2}\right)$ in 3 replications. Sowing quantities, (expressed in grams per $1 \mathrm{~m}^{2}$ ) ranged from 10 for Poa pratensis, 15 for Festuca rubra, F. ovina, F. nigrescens, 20 for Lolium perenne, Festuca arundinacea and 25 for all turf mixtures. Turf plots were further managed without fertilization, with mowing at $7-10 \mathrm{~cm}$, ca. 10 times a year with clippings collected, watered only during heavy drought and with no chemical weed control. Visual merit (VM) and shoot density (SD) were evaluated 5 times a year (early spring, spring, summer, autumn and winter) using $1-9$ scale. For VM rating value of 9 is reserved for a perfect or ideal grass, rating of 6 is generally considered acceptable and 1 - poorest (Morris and Sherman, 2007). For shoot density 9 means maximum density (100\%), $7-$ ca. $80 \%$ of ground covered by leaves and tillers, $5-\mathrm{ca}$. $60 \%, 3-\mathrm{ca}$. $20 \%$ and $1-0 \%$, no green cover (Prończuk, 1993). For the purpose of above work, yearly means od SD and VM from 2002 and 2006 were only given and further analyzed. Weed cover (WC) expressed as a\% of plot cover by weed species (i.e. dicotyledonous plant species and grasses not sown) was assessed in autumn of 2003 and 2006, and average number of weed species (NWS) per entry was calculated. All data were subjected to arcsine transformation for better approximation to normal distribution prior to statistical analysis performed with $S A S^{\circledR}$ statistical package. Least significant difference (LSD) was performed with Fisher test $(\mathrm{P}=0.05)$.

\section{RESULTS AND DISCUSSION}

One from the most important traits for low maintenance turf is the ability to cover ground, which is of great utilitarian purpose of stabilizing soil (reduction of dust, mud or weed problems) (Diesburg et al. 1997). Ground cover was not directly evaluated in our experiment, however it could be indirectly expressed by means of shoot density (SD). Mentioned trait decreased for most of tested entries after 5 years of low maintenance management (Table 2). Low reduction of SD was noted for Festuca ovina ssp. duriuscula ESPRO and all mixtures with low share of Lolium perenne ( 86.5 and $82.9 \%$ of initial value, respectively). In contrast, high SD reduction was observed for Festuca nigrescens LIFALLA, mixture no. 2 (high share of Lolium perenne) and Festuca nigrescens WOM-198 (62.5, 64.0 and $65.1 \%$ of initial value, respectively).

Visual merit (VM) of tested entries also decreased with different rates after 5 years. Relatively low decrease of VM (range from 86.4 to $82.0 \%$ of initial value) was noted for all Festuca ovina ssp. duriuscula cultivars as well as for Festuca arundinacea SKARPA and TERROS, and two mixtures of 


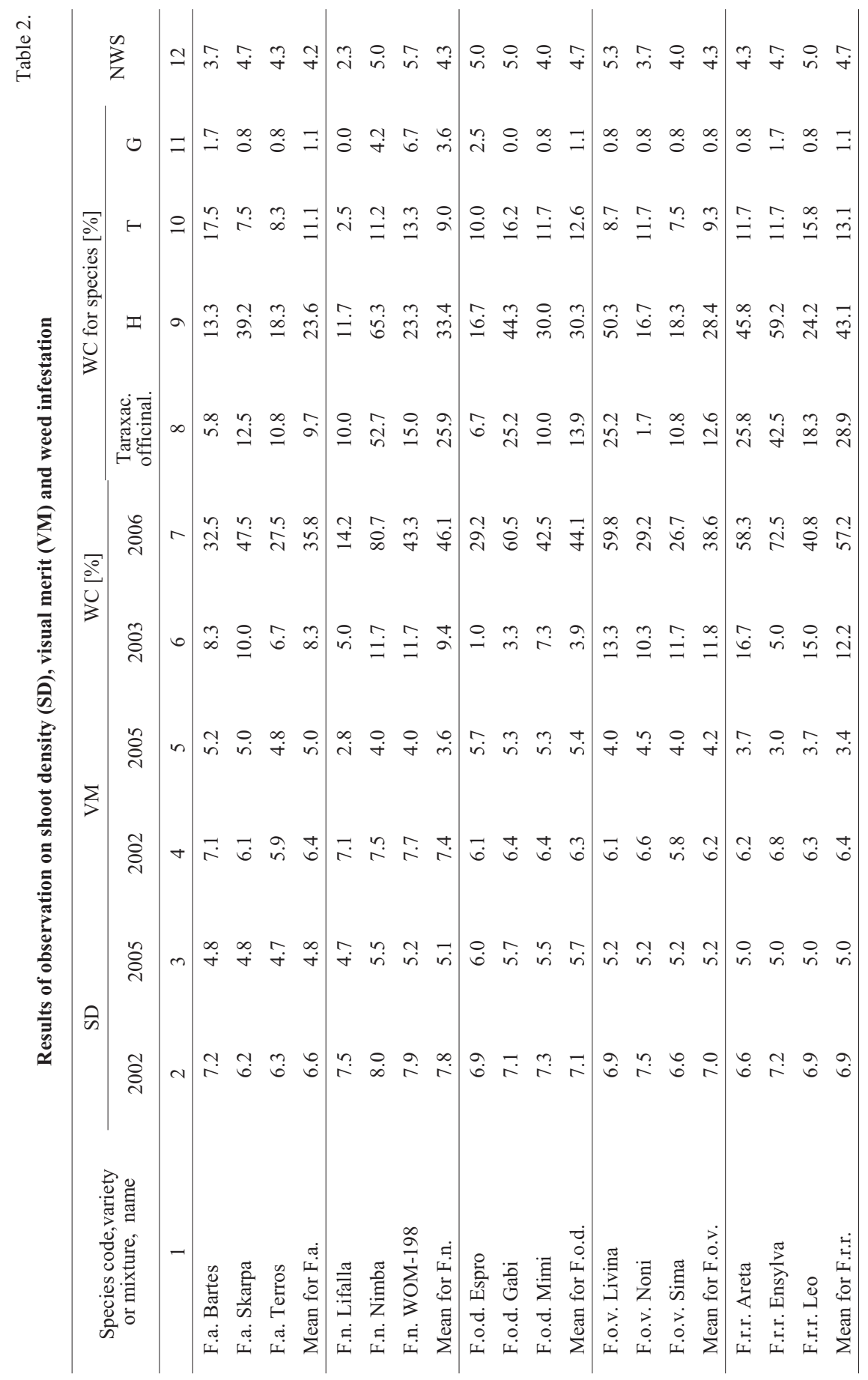




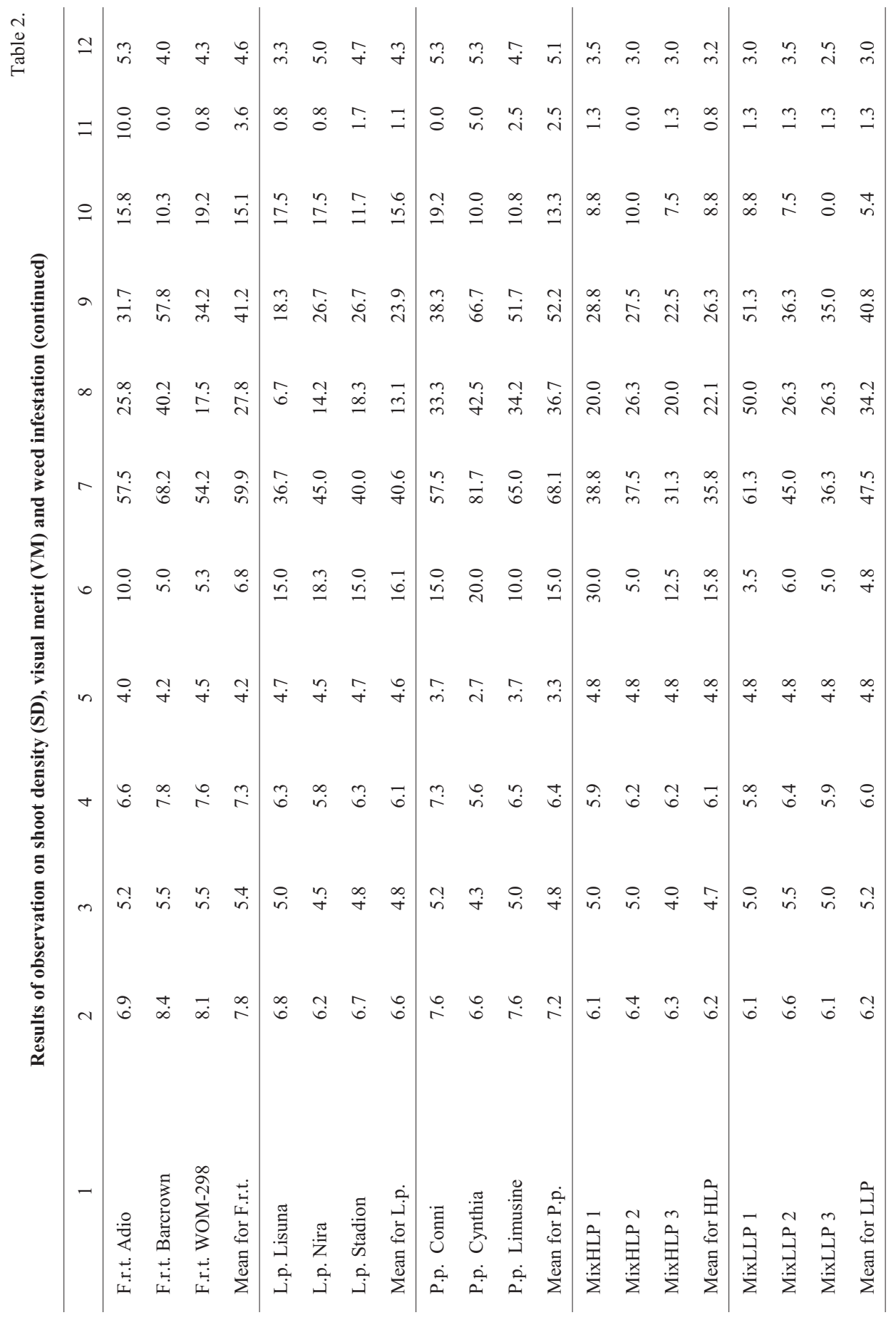


low share of Lolium perenne (no. 4 and 5). High quality of tall and sheep fescue in low-maintenance was also confirmed by others (Dernoeden et al. 1998; Diesburg et al. 1997; Brede 2000). High VM decrease (ca. 50\% or more than initial value) was noted for all Poa pratensis cultivars, Festuca nigrescens LIFALLA and Festuca rubra ssp. rubra ENSYLVA. Turfgrass varieties and species are known to differ in their performance under reduced maintenance (Brede, 2000).

Table 3.

Weed species identified and weed cover values (WC) after 4 years on low-maintenance

\begin{tabular}{|c|c|c|c|c|c|}
\hline \multirow[b]{2}{*}{ No. } & \multirow[b]{2}{*}{ Genus, species, authority } & \multirow[b]{2}{*}{ Living form } & \multicolumn{3}{|c|}{$\mathrm{WC}[\%]$} \\
\hline & & & Average & Range & $\begin{array}{l}\text { Standard } \\
\text { deviation }\end{array}$ \\
\hline 1 & Taraxacum officinale Weber & $\mathrm{H}$ & 22.4 & $0-62.5$ & 20.02 \\
\hline 2 & Trifolium campestre Schreber & $\mathrm{T}$ & 9.19 & $0-37.5$ & 8.55 \\
\hline 3 & Trifolium repens $\mathrm{L}$. & $\mathrm{C}$ & 6.48 & $0-37.5$ & 10.48 \\
\hline 4 & Hieracium pilosella $\mathrm{L}$. & $\mathrm{H}$ & 3.03 & $0-28$ & 4.47 \\
\hline 5 & Equisetum arvense L. & G & 1.63 & $0-37.5$ & 4.01 \\
\hline 6 & Helichrysum arenarium (L.) Moench & $\mathrm{H}$ & 0.74 & $0-15$ & 2.43 \\
\hline 7 & Hypericum perforatum L. & $\mathrm{H}$ & 0.55 & $0-2.5$ & 1.04 \\
\hline 8 & Plantago lanceolata $\mathrm{L}$. & $\mathrm{H}$ & 0.41 & $0-2.5$ & 0.93 \\
\hline 9 & Conyza canadensis (L.) Cronq. & $\mathrm{T}, \mathrm{H}$ & 0.27 & $0-2.5$ & 0.77 \\
\hline 10 & Erucastrum gallicum (Willd.) O. E. Schulz & $\mathrm{T}, \mathrm{H}$ & 0.25 & $0-2.5$ & 0.75 \\
\hline 11 & Cichorium intybus L. & $\mathrm{H}$ & 0.16 & $0-2.5$ & 0.61 \\
\hline 12 & Diplotaxis muralis (L.) DC. & $\mathrm{T}$ & 0.13 & $0-2.5$ & 0.55 \\
\hline 13 & Dactylis glomerata L. & $\mathrm{H}$ & 0.09 & $0-2.5$ & 0.48 \\
\hline 14 & Solidago canadensis L. & $\mathrm{H}, \mathrm{G}$ & 0.08 & $0-2.5$ & 0.44 \\
\hline 15 & Vicia cracca $\mathrm{L}$. & $\mathrm{H}$ & 0.06 & $0-2.5$ & 0.39 \\
\hline 16 & Lotus corniculatus L. & $\mathrm{H}$ & 0.05 & $0-2.5$ & 0.34 \\
\hline 17 & Astragallus glycyphyllos L. & $\mathrm{H}$ & 0.03 & $0-2.5$ & 0.28 \\
\hline 18 & Hypochoeris glabra L. & $\mathrm{T}$ & 0.03 & $0-2.5$ & 0.28 \\
\hline 19 & Artemisia vulgaris L. & $\mathrm{C}$ & 0.02 & $0-2.5$ & 0.20 \\
\hline 20 & Cirsium arvense (L.) Scop. & G & 0.02 & $0-2.5$ & 0.20 \\
\hline
\end{tabular}

Explanation for living forms: $\mathrm{H}$ - hemicryptophyte, $\mathrm{T}$ - terophyte, $\mathrm{G}$ - geophyte, $\mathrm{C}$ - chamephyte

Total number of 20 weed species was identified, most of them $(75 \%)$ perennials, with no statistical difference of species cover between replications and tested entries (Tables 2, 3). However, for turf grass species, significant differences were calculated for 14 of all identified weed species. Average number of weed species was the highest for Poa pratensis (5.1) but the lowest for turf mixtures $(3.0-3.2)$. Weed cover (WC) values were the 
highest for Poa pratensis and Festuca rubra ssp. trichophylla (68.1 and $59.9 \%$, respectively) and the lowest for mixtures of high share of Lolium perenne, Festuca arundinacea (35.8\% for both), Festuca ovina ssp. vulgaris and Lolium perenne (38.6 and 40.6\%, respectively). Similar results concerning weed infestation of Poa pratensis, Lolium perenne, Festuca ovina, $F$. arundinacea were obtained in low maintenance turf trails in Canada by McKernan and Ross (1993; 1996 after Brede 2000).

Weeds of the highest WC values were: Taraxacum officinale Weber (22.8\%), Trifolium campestre Schreber (9.2\%), T. repens L. (6.5\%) and Hieracium pilosella L. (3.0\%). Despite of the lack of statistically significant differences between entries, the lowest Taraxacum cover was noted for: Festuca ovina ssp. vulgaris NONI, Festuca arundinacea BARTES, Festuca ovina ssp. duriuscula ESPRO, and Lolium perenne LISUNA (1.7, 5.8, 6.7, 6.7\%, respectively). The highest Taraxacum cover were observed on Festuca rubra ssp. trichophylla BARCROWN, Poa pratensis CYNTHIA, Festuca rubra ssp. rubra ENSYLVA, mixture no. 4 (low share of Lolium perenne) and Festuca nigrescens NIMBA (40.2, 42.5, 42.5, 50, $52.7 \%$, respectively). Probably due to its highest cover values, Taraxacum was the only species that negatively affected final VM value $(r=-0.42 * *)$.

Weed cover increased over time, but with different magnitudes. High increase $\left(\mathrm{WC}_{2006}-\mathrm{WC}_{2003}\right)$ was noted for Festuca rubra ssp. trichophylla, Poa pratensis and mixtures of high share of Lolium perenne, as well as for cultivars of Lolium perenne amd Festuca ovina ssp. duriuscula (20.0, 24.5 and $26.8 \%$, respectively).

Weeds on low managed turfs are in many cases dominating components of sward. Weed infestation on Warsaw city turfs ranged from 41 to $76 \%$ (Wysocki, Stawicka 2000). Relatively high share of terophytes (annual species) in our experiment is similar to results obtained by Wysocki and Stawicka (2000). Such relation is negative for turf, but we have noticed relatively low values of terophytes cover in mixtures of low share of Lolium perenne (5.4\%) as compared to other entries (range from 8.8 for mixtures of high share of Lolium perenne to $15.6 \%$ for Lolium perenne). Geophytes and hemicrypthophytes accounted for majority $(70 \%)$ of identified weed species. It was also confirmed by Wysocki (1994) and Wysocki and Stawicka (2000) on turf areas in parks.

Turf weed infestation is differently affected by irrigation, fertilization and mowing (Fry, Huang 2004). Water is necessary to germination and emergence of weeds, but each year it is quite narrow 'window' during which winter or summer annuals emerge. Therefore, if low maintained areas are not artificially watered, annual weeds invasion will not be stimulated. Turf receiving inadequate levels of fertilizers, especially nitrogen, is generally not resistant to weed invasion. Nitrogen fixing weeds as clovers could be therefore quite frequent, as in our experiment $(15.7 \%$ of weed 
cover). In contrast, mowing with clippings collected may reduce weed populations, mostly of seed producers (Fry and Huang 2004).

Weeds on large, low managed municipal areas (parks, gardens, cemeteries etc.) are inherent component of turf. However, still much has to be done to balance the share of weeds and grasses on turf sward. Otherwise, turf will no longer be green area but the initial stage of succession of unpredictable direction.

\section{CONCLUSIONS}

None of tested varieties and mixtures was able to keep initial values of shoot density and visual merit after 5 years of reduced maintenance.

Despite of initial differences in visual merit, turf mixtures were very similar after given time of experiment with no differences inside or between group of mixtures.

Turf mixtures of low share of Lolium perenne should be recommended for low maintenance turfs due to its relatively high turf quality, high ability to cope with weeds and known significantly lower input requirements considering mowing.

\section{REFERENCES}

Brede D. 2000. Turfgrass Maintenance Reduction Handbook: Sports, Lawns and Golf. Ann Arbor Press, Chelsea, Michigan, USA, pp. 374.

Dernoeden P.H., Carroll M.J., Krouse M.J. 1993. Weed management and tall fescue quality as influenced by mowing, nitrogen, and herbicides. Crop Sci. 33: 10155-1061.

Dernoeden P. H., Fidanza M. A., Krouse M. J. 1998. Low maintenance performance of five Fescue species in monostands and mixtures. Crop Sci. 38, 2: 434 - 438.

Diesburg K.L., Christians N.E., Moore R., Branham B., Danneberger T.K., Reicher Z. J., Voigt T., Minner D.D., Newman R.. 1997. Species for low-input sustainable turf in the U.S. Upper Midwest. Agron. J. vol. 89 , no. 4; 690 - 694 .

Fry J., Huang B. 2004. Applied Turfgrass Science and Physiology. John Wiley \& Sons, Inc., Hoboken, New Jersey, pp. 310.

Mintenko A. S., Smith R.S., Cattani D.J. 2002. Turfgrass evaluation of native grasses for the Northern Great Plain regions. Crop Sci. 42: $2018-2024$.

Morris K.N., Sherman R.C., 2007. NTEP Turfgrass Evaluation Guidelines. via internet: http://www.ntep.org/pdf/ratings.pdf

Prończuk S. 1993. System oceny traw gazonowych. Biul. IHAR, 186: $127-132$.

Wysocki C. 1994. Studia nad funkcjonowaniem trawników na obszarach zurbanizowanych (na przykładzie Warszawy). Rozprawy i Monografie Naukowe. Wydawnictwo SGGW; 1 - 95

Wysocki C., Stawicka J. 2000. Ocena zmian florystycznych runi trawników miejskich. Łąkarstwo w Polsce (Grassland Science in Poland), 3: 169 - 176. 